\title{
Effect of Different Copper Levels in Feed on Antioxidant Capacity in Stocking the Native Sheep in the Wumeng Prairie
}

\author{
Ting Wu ${ }^{1,2}$, Kangning Xiong ${ }^{3}$, Jian $\mathrm{He}^{1,2 *}$ \\ ${ }^{1}$ School of Life Science and Engineering, Southwest University of Science and Technology, Mianyang, China \\ ${ }^{2}$ Feng Guang De Laboratory, Tie Qi Li Shi Group, Mianyang, China \\ ${ }^{3}$ State Engineering Technology Institute for Karst Desertification Control, Guizhou Normal University, Guiyang, China
}

Received: 14 October 2020

Accepted: 18 December 2020

\begin{abstract}
The purpose of this research is to better understand the effect of different copper $(\mathrm{Cu})$ levels of feed on the antioxidant capacity in the native sheep, solve the adverse effects of local seasonal Cu deficiency on sheep, and provide a reasonable reference for $\mathrm{Cu}$ supplementation. 10 healthy native sheep were selected as the control group ( $\mathrm{C}$ group). $40 \mathrm{Cu}$-deficient native sheep were selected as tested group, and divided randomly into 4 groups $(\mathrm{n}=10)$, supplied by $\mathrm{CuSO}_{4}(0,20,40,60 \mathrm{mg} / \mathrm{kg}$ for group I, group II, group III and group IV, respectively). The results showed that the level of $\mathrm{Cu}$, hemoglobin $(\mathrm{Hb})$, packed-cell volume (PCV), albumin (ALB), the activities of ceruloplasmin (CP), Cu/ $\mathrm{Zn}$ superoxide dismutase $(\mathrm{Cu} / \mathrm{Zn}$-SOD) and catalase (CAT) in group I were significantly lower than those in C group, group II, III, IV $(P<0.05)$, but malondialdehyde (MDA) concentration was higher. The activities of these antioxidant enzymes and MDA concentration had no significant difference between C group, group II, III, IV $(P>0.05)$, but group III had the highest antioxidant enzymes activity and the lowest MDA concentration. There was no significant difference in manganese $(\mathrm{Mn})$, zinc $(\mathrm{Zn})$, iron (Fe), molybdenum (Mo), selenium (Se), red blood cell count (RBC), white blood cell count (WBC), blood urea nitrogen (BUN), alanine transaminase (ALT), alkaline phosphatase (ALP), aspartate aminotransferase (GOT), total cholesterol (TC), manganese-superoxide dismutase (Mn-SOD) between all groups $(P>0.05)$. Conclusion: The function of antioxidant system of the native sheep in Weining County have seriously reduced. Added $\mathrm{CuSO}_{4}$ to the diet increase the activity of antioxidant enzymes and improve the health parameters, but them did not increase linearly. Added $40 \mathrm{mg} / \mathrm{kg} \mathrm{CuSO}$, the activity of antioxidant enzymes was the highest and the content of MDA was the lowest. Therefore, it is recommended to add $40 \mathrm{mg} / \mathrm{kg} \mathrm{CuSO}_{4}$ to diet of the native sheep in Weining County.
\end{abstract}

Keywords: the native sheep, different copper level, physiological parameter, biochemical parameter, antioxidant system

*e-mail: xkdhejian@163.com 


\section{Introduction}

The native sheep, whose original name was Guizhou semi-fine wool sheep, is a sheep breed hybrid developed by crossing local Tibetan sheep with other breeds [1]. Hence, it has some excellent characteristics, such as good adaptability, greater resistance to disease, great ability of enduring roughage, obedient disposition, easy management, and the quality requirements of forage is not high $[2,3]$.

Copper $(\mathrm{Cu})$ as one of the essential trace elements of animal, plays an irreplaceable role in hematopoiesis, metabolism, growth and reproduction, maintenance of growth performance and enhancement resistance in body [4]. Lack or excess of $\mathrm{Cu}$ will affect the health and performance in animals [5]. $\mathrm{Cu}$ deficiency in animals can lead to tissue damage, and reduce meat, wool, milk and lambing rate, etc. Severe $\mathrm{Cu}$ deficiency in animals can cause obvious clinical symptoms, such as lackluster clothing hair, joint deformity, decreased reproductive capacity, neurological disorders, ataxia, anemia, even death [6,7]. $\mathrm{Cu}$ excesses can also cause loss of appetite, bradykinesia, hemolytic anemia and other symptoms [8-10]. Cu nutrient not only participates in the production of superoxide dismutase (SOD) and ceruloplasmin (CP) but also plays a key role in antioxidant system [11, 12]. Antioxidant system, a defense system of the organisms to free radicals, include the enzymatic and nonenzymatic system $[4,13,14]$. The non-enzymatic system comprise mainly vitamin, cysteine, glutathione (GSH) and mineral element. The enzymatic system consists of antioxidant enzymes, including mainly CAT, SOD and GSH-Px. Antioxidant system can catalyze rapidly the superoxide anion $\left(\mathrm{O}^{2-}\right)$ to produce disproportionation reaction, eliminate superoxide anion, and protect cells of organism from damage of free radicals [15-18]. $\mathrm{Cu}$ supplementation, in the range of growth promotion, can increase activities of GSH-Px, SOD and CP in serum in cattle, pigs and chickens [17]. Li et al. [19] reported that when the Mo level was $0.27 \mathrm{mg} / \mathrm{kg}$ in beef cattle diet, adding $10 \mathrm{mg} / \mathrm{kg} \mathrm{Cu}$ could meet the needs of the body, when the Mo level was $5.27 \mathrm{mg} / \mathrm{kg}$ in beef cattle diet, adding $25 \mathrm{mg} / \mathrm{kg} \mathrm{Cu}$ was more appropriate. Zhang et al. [20] pointed out that the optimum additive amount of $\mathrm{Cu}$ based on basic diet (actual measured $\mathrm{Cu}$ content in the basic diet was $4.85 \mathrm{mg} / \mathrm{kg}$ ) was $30.0 \mathrm{mg} /$ $\mathrm{kg}$, which was the most beneficial to immune function and antioxidant enzyme activity of the growing laying hens. Zhang et al. [21] added different levels of $\mathrm{Cu}$ to the diet of White Cashmere Goats during the cashmere growing period, the results showed that the growth rate of villi in the $20 \mathrm{mg} / \mathrm{kg} \mathrm{Cu}$ group was significantly higher than that in the $10 \mathrm{mg} / \mathrm{kg}$ group, but there was no significant difference between the $30 \mathrm{mg} / \mathrm{kg} \mathrm{Cu}$ and the $20 \mathrm{mg} / \mathrm{kg} \mathrm{Cu}$. However, the effects of different $\mathrm{Cu}$ content in diet on antioxidant enzymes of native sheep were not clear, and the appropriate supplemental level of $\mathrm{Cu}$ in diet was not reported in $\mathrm{Cu}$-deficient native sheep [22].
The objective of this experiment is to solve the problem of seasonal $\mathrm{Cu}$ deficiency causing adverse effects on antioxidant capacity in the native sheep and provide a scientific basis for the rational addition of $\mathrm{Cu}$ in feeds for the native sheep.

\section{Materials and Methods}

\section{Experimental Design}

10 healthy native sheep, 6-month-old, were selected as the control group (C group) in Dushan County, Guizhou Province, Southwest China, where the environment mineral elements are within the normal range value. $40 \mathrm{Cu}$-deficient native sheep, 6-monthold, were selected as tested group in Weining County, Guizhou Province, where $\mathrm{Cu}$ is lacking. $\mathrm{Cu}$-deficient native sheep were divided randomly into 4 tested groups (n = 10), and supplying $\mathrm{CuSO}_{4}(0,20,40,60 \mathrm{mg} / \mathrm{kg}$ for group I, group II, group III and group IV, respectively) [23]. The feeding test was carried out for 60 days, and the jugular vein blood was collected in the morning at the end of the feeding experiment, to measure the blood indexes. During the 60-day feeding experiment, C group and group I native sheep maintained the original growth environment and feeding level, as reference.

\section{Sample Collection}

On the morning of the end of the feeding trial, the jugular blood of the animals used was collected by aseptic vacuum tubes, collected $20 \mathrm{~mL}$ per sheep, keep it at low temperature $\left(4-8^{\circ} \mathrm{C}\right)$, and transported back to the laboratory within 4 hours.

\section{Determination and Method}

\section{Mineral Element Content}

The contents of manganese (Mn), zinc ( $\mathrm{Zn})$, copper $(\mathrm{Cu})$, iron $(\mathrm{Fe})$, molybdenum (Mo) and selenium (Se) in blood were determined by XDY-2A atomic absorption spectrometer (PerkinElmer, Inc., Waltham, MA, USA).

\section{Blood Physiological and Biochemical Indicators}

Hemoglobin $(\mathrm{Hb})$, red blood cell count (RBC), packed-cell volume (PCV) and white blood cell count (WBC) in blood were measured by using automatic blood cell analyzer (SF-3000; Sysmex Corporation, Kobe, Japan). The activity or content of albumin (ALB), blood urea nitrogen (BUN), alanine transaminase (ALT), alkaline phosphatase (ALP), aspartate aminotransferase (GOT), total cholesterol (TC), ceruloplasmin (CP), copper/zinc-Superoxide dismutase $(\mathrm{Cu} / \mathrm{Zn}$-SOD), manganese-superoxide 
Table 1. Effect of $\mathrm{Cu}$ level on mineral content in blood in native sheep.

\begin{tabular}{|c|c|c|c|c|c|}
\hline Element & C group & Group I & Group II & Group III & Group IV \\
\hline $\mathrm{Mn}\left(\mu \mathrm{g} \cdot \mathrm{g}^{-1}\right)$ & $0.242 \pm 0.031$ & $0.249 \pm 0.025$ & $0.243 \pm 0.025$ & $0.243 \pm 0.032$ & $0.244 \pm 0.031$ \\
\hline $\mathrm{Zn}\left(\mu \mathrm{g} \cdot \mathrm{g}^{-1}\right)$ & $0.523 \pm 0.023$ & $0.516 \pm 0.024$ & $0.529 \pm 0.048$ & $0.518 \pm 0.038$ & $0.517 \pm 0.030$ \\
\hline $\mathrm{Cu}\left(\mu \mathrm{g} \cdot \mathrm{g}^{-1}\right)$ & $1.28 \pm 0.19 \mathrm{a}$ & $0.63 \pm 0.18 \mathrm{~b}$ & $1.21 \pm 0.15 \mathrm{a}$ & $1.29 \pm 0.18 \mathrm{a}$ & $1.34 \pm 0.19 \mathrm{a}$ \\
\hline $\mathrm{Fe}\left(\mu \mathrm{g} \cdot \mathrm{g}^{-1}\right)$ & $437.3 \pm 9.0$ & $431.4 \pm 9.1$ & $436.3 \pm 12.2$ & $432.5 \pm 10.6$ & $433.6 \pm 9.8$ \\
\hline $\mathrm{Mo}\left(\mu \mathrm{g} \cdot \mathrm{g}^{-1}\right)$ & $0.231 \pm 0.018$ & $0.215 \pm 0.025$ & $0.228 \pm 0.023$ & $0.228 \pm 0.025$ & $0.218 \pm 0.023$ \\
\hline $\mathrm{Se}\left(\mu \mathrm{g} \cdot \mathrm{g}^{-1}\right)$ & $0.087 \pm 0.016$ & $0.0912 \pm 0.012$ & $0.0927 \pm 0.013$ & $0.087 \pm 0.005$ & $0.084 \pm 0.003$ \\
\hline
\end{tabular}

$\mathrm{Mn}=$ manganese, $\mathrm{Zn}=$ zinc, $\mathrm{Cu}=$ copper, $\mathrm{Fe}=$ iron, $\mathrm{Mo}=$ molybdenum, $\mathrm{Se}=$ selenium

Note: different little letters show significant difference $(P<0.05)$.

dismutase (Mn-SOD), catalase (CAT), glutathione peroxidase (GSH-Px) and malondialdehyde (MDA) were detected by using automatic biochemical analyzer (MindrayBS-420, China).

\section{Data Analysis}

SPSS 20.0 (version 20.0 for windows, Chicago, Illinois, USA) was used to analyze the effects of the dietary $\mathrm{Cu}$ levels on measures. Multiple mean comparisons were performed using one-way ANOVA. Data are presented as (means \pm S.D.).

\section{Results}

\section{Effect of Cu Level on Mineral Element Content in Blood}

The effect of feed with different $\mathrm{Cu}$ level on the mineral content in blood is shown in Table 1. The content of $\mathrm{Cu}$ in blood in group I (deficient sheep) was significantly lower than that in $\mathrm{C}$ group (healthy sheep) $(P<0.05)$, while the contents of Mn, Zn, Mo, Fe and $\mathrm{Se}$ were no significant difference between group I and $\mathrm{C}$ group $(P>0.05)$. With the increase of $\mathrm{Cu}$ content in diet, the content of $\mathrm{Cu}$ in blood gradually increases, group IV $>$ group II $>\mathrm{C}$ group $>$ group II $(P>0.05)$, group II $>$ group I $(P<0.05)$, while the contents of $\mathrm{Mn}, \mathrm{Zn}$, Mo, Fe and Se was no significant change $(P>0.05)$.

\section{Effects of $\mathrm{Cu}$ Levels on Blood Index}

The effect of feed with different $\mathrm{Cu}$ level on blood index in native sheep is shown in Table 2. The $\mathrm{Hb}$, and $\mathrm{PCV}$ in group I were significantly lower than those in $\mathrm{C}$ group $(P<0.05)$. There was no significant difference in the number of RBC and WBC between two groups $(P>0.05)$. With the increases of $\mathrm{Cu}$ content in diet, $\mathrm{Hb}$ and $\mathrm{PCV}$ were increased $(P<0.05)$, and there was a tendency to increase with the increase of $\mathrm{Cu}$ dosage, but no significant increase between $\mathrm{Cu}$ addition groups $(P>0.05)$. In addition, the change of $\mathrm{Cu}$ level did not cause significant changes in the number of $\mathrm{RBC}$ and WBC $(P>0.05)$.

\section{Effect of Different $\mathrm{Cu}$ Levels on Blood Biochemical Value}

The effect of feed with different $\mathrm{Cu}$ level on blood biochemical value in native sheep is shown in Table 3. The content of ALB in group I were significantly lower than those in $\mathrm{C}$ group $(P<0.05)$. With the dietary $\mathrm{Cu}$ content increase, the content of ALB increased gradually, but there was no significant difference between the $\mathrm{CuSO}_{4}$ addition groups $(P>0.05)$. There were no significant differences in BUN, ALT, ALP, GOT and TC activities between C group, group I, group II, group III and group IV $(P>0.05)$.

Table 2. Effect of $\mathrm{Cu}$ level on blood index in native sheep.

\begin{tabular}{|c|c|c|c|c|c|}
\hline Blood indices & Control group & Group I & Group II & Group III & Group IV \\
\hline Hb $\left(\mathrm{g} \cdot \mathrm{L}^{-1}\right)$ & $138.2 \pm 3.2 \mathrm{a}$ & $101.4 \pm 3.2 \mathrm{~b}$ & $129.1 \pm 3.1 \mathrm{a}$ & $135.1 \pm 3.3 \mathrm{a}$ & $135.9 \pm 3.1 \mathrm{a}$ \\
\hline RBC $\left(\times 10^{12} \cdot \mathrm{L}^{-1}\right)$ & $17.91 \pm 3.15$ & $16.92 \pm 1.79$ & $17.48 \pm 1.92$ & $17.98 \pm 2.80$ & $17.44 \pm 1.81$ \\
\hline PCV $(\%)$ & $43.11 \pm 3.57 \mathrm{a}$ & $31.89 \pm 2.04 \mathrm{~b}$ & $41.01 \pm 2.36 \mathrm{a}$ & $42.32 \pm 3.48 \mathrm{a}$ & $41.92 \pm 2.11 \mathrm{a}$ \\
\hline WBC $\left(\times 10^{9} \cdot \mathrm{L}^{-1}\right)$ & $8.43 \pm 2.37$ & $9.26 \pm 1.93$ & $9.05 \pm 1.79$ & $8.93 \pm 2.12$ & $9.23 \pm 1.75$ \\
\hline
\end{tabular}

$\mathrm{Hb}=$ hemoglobin, $\mathrm{RBC}=$ red blood cell count, $\mathrm{PCV}=$ packed-cell volume, $\mathrm{WBC}=$ white blood cell count

Note: different little letters show significant difference $(P<0.05)$. 
Table 3. Effect of $\mathrm{Cu}$ level on biochemical value in blood in the native sheep.

\begin{tabular}{|c|c|c|c|c|c|}
\hline Biochemical values & C group & Group I & Group II & Group III & Group IV \\
\hline ALB $\left(\mathrm{g} \cdot \mathrm{L}^{-1}\right)$ & $28.73 \pm 2.87 \mathrm{a}$ & $27.45 \pm 3.25 \mathrm{~b}$ & $29.73 \pm 2.84 \mathrm{a}$ & $31.45 \pm 3.15 \mathrm{a}$ & $30.95 \pm 3.20 \mathrm{a}$ \\
\hline BUN $\left(\mathrm{mmol} \cdot \mathrm{L}^{-1}\right)$ & $6.12 \pm 2.01$ & $7.12 \pm 1.85$ & $6.57 \pm 1.92$ & $6.24 \pm 1.80$ & $5.77 \pm 1.72$ \\
\hline ALT $\left(\mathrm{IU} \cdot \mathrm{L}^{-1}\right)$ & $11.41 \pm 1.87$ & $12.39 \pm 2.08$ & $11.91 \pm 2.51$ & $11.11 \pm 2.42$ & $10.31 \pm 1.96$ \\
\hline ALP $\left(\mathrm{IU} \cdot \mathrm{L}^{-1}\right)$ & $291.61 \pm 13.21$ & $281.84 \pm 19.52$ & $287.33 \pm 18.83$ & $291.01 \pm 19.25$ & $295.87 \pm 17.26$ \\
\hline GOT $\left(\mathrm{IU} \cdot \mathrm{L}^{-1}\right)$ & $36.24 \pm 2.90$ & $34.94 \pm 3.19$ & $35.84 \pm 2.40$ & $35.34 \pm 2.98$ & $36.14 \pm 3.09$ \\
\hline TC $\left(\mathrm{mmol} \cdot \mathrm{L}^{-1}\right)$ & $2.67 \pm 0.28$ & $2.55 \pm 0.26$ & $2.61 \pm 0.24$ & $2.64 \pm 0.18$ & $2.59 \pm 0.20$ \\
\hline
\end{tabular}

$\mathrm{ALB}=$ albumin, $\mathrm{VUN}=$ blood urea nitrogen, $\mathrm{ALT}=$ alanine transaminase, $\mathrm{ALP}=$ alkaline phosphatase

$\mathrm{GOT}=$ aspartate aminotransferase, $\mathrm{TC}=$ total cholesterol

Note: different little letters show significant difference $(P<0.05)$.

\section{Effects of Different Cu Levels on Antioxidant Capacity}

The effect of feed with different $\mathrm{Cu}$ level on antioxidant index in native sheep is showed in Table 4 . The activity of CP, Cu/Zn-SOD, CAT and GSH$P x$ in blood in group I were significantly lower than those in $\mathrm{C}$ group $(P>0.05)$, and the content of MDA was significantly higher than that in $\mathrm{C}$ group $(P>0.05)$, while the activity of Mn-SOD had no significant difference between two groups $(P>0.05)$. After adding different level $\mathrm{CuSO}_{4}$ to diet, the activity of $\mathrm{CP}, \mathrm{Cu} / \mathrm{Zn}$ SOD, CAT and GSH-Px in blood in the native sheep was group III $>$ group IV $>$ group II $>$ group I $(P>0.05)$, and the MDA concentration in blood was group III $<$ group IV< $<$ group II $<$ group I $(P>0.05)$. In addition, MnSOD was little affected by the change of $\mathrm{Cu}$ level, had no significant difference between the $\mathrm{C}$ group and the experimental groups $(P>0.05)$.

\section{Discussion}

Oxygen free radicals are the main free radicals in animal body, and even accounting for $95 \%$ of the total. There is a dynamic balance between oxygen free radicals' generating and scavenging in health body to ensure body's health [24]. However, when the generation of oxygen free radicals exceeds the body's scavenging capacity, there will be a disorder of redox balance, resulting in damage to a variety of macromolecules (DNA, protein, lipid), and then lead to the occurrence and development of diseases $[25,26]$.

The antioxidant system of organism is the scavenging system of oxygen free radicals, including enzymatic scavenging system and non-enzymatic scavenging system. It plays a key role in resist antioxidant damage and maintaining oxidation-reduction balance. The enzymes involved in enzymatic scavenging system include GSH-Px, SOD and CAT [27]. Cu is an essential element for animal growth and development. As a component of enzymes, $\mathrm{Cu}$ participates in animal metabolism and plays an important role in enhancing the function of antioxidant system [28]. The results shown that the activity of $\mathrm{CP}, \mathrm{Cu} / \mathrm{Zn}-\mathrm{SOD}, \mathrm{GSH}-\mathrm{Px}$ and CAT in blood in group I were significantly lower than those in $\mathrm{C}$ group, while the MDA content was significantly higher than that in $\mathrm{C}$ group, which indicated that when the animal lack $\mathrm{Cu}$ in their diet, the body's antioxidant ability will be reduced. The activity of $\mathrm{CP}, \mathrm{Cu} / \mathrm{Zn}$-SOD, GSH-Px and CAT in group III were kept at the highest level, while the contents of MDA were at the lowest

Table 4. Effect of $\mathrm{Cu}$ level on antioxidant index in blood in the native sheep.

\begin{tabular}{|c|c|c|c|c|c|}
\hline Antioxidant indexes & C group & Group I & Group II & Group III & Group IV \\
\hline CP $\left(\mathrm{mg} \cdot \mathrm{L}^{-1}\right)$ & $50.68 \pm 2.19 \mathrm{a}$ & $44.21 \pm 1.97 \mathrm{~b}$ & $49.07 \pm 3.17 \mathrm{a}$ & $53.57 \pm 2.69 \mathrm{a}$ & $52.68 \pm 1.74 \mathrm{a}$ \\
\hline $\mathrm{Cu} / \mathrm{Zn}-\mathrm{SOD}\left(\mathrm{U} \cdot \mathrm{L}^{-1}\right)$ & $18.58 \pm 1.71 \mathrm{a}$ & $15.32 \pm 1.32 \mathrm{~b}$ & $17.77 \pm 2.06 \mathrm{a}$ & $18.72 \pm 2.15 \mathrm{a}$ & $18.54 \pm 1.38 \mathrm{a}$ \\
\hline Mn-SOD $\left(\mathrm{U} \cdot \mathrm{L}^{-1}\right)$ & $11.22 \pm 1.60$ & $9.92 \pm 1.64$ & $10.81 \pm 1.86$ & $11.37 \pm 1.61$ & $11.36 \pm 1.65$ \\
\hline CAT $\left(\mathrm{U} \cdot \mathrm{L}^{-1}\right)$ & $1.97 \pm 0.18 \mathrm{a}$ & $1.54 \pm 0.18 \mathrm{~b}$ & $1.88 \pm 0.19 \mathrm{a}$ & $1.96 \pm 0.23 \mathrm{a}$ & $1.92 \pm 0.15 \mathrm{a}$ \\
\hline GSH-Px $\left(\mathrm{U} \cdot \mathrm{L}^{-1}\right)$ & $23.48 \pm 2.13 \mathrm{a}$ & $17.74 \pm 2.04 \mathrm{~b}$ & $23.07 \pm 2.54 \mathrm{a}$ & $23.88 \pm 1.92 \mathrm{a}$ & $23.25 \pm 2.47 \mathrm{a}$ \\
\hline MDA $\left(\mathrm{nmol} \cdot \mathrm{L}^{-1}\right)$ & $22.05 \pm 2.17 \mathrm{a}$ & $31.87 \pm 3.64 \mathrm{~b}$ & $23.34 \pm 3.02 \mathrm{a}$ & $21.95 \pm 2.46 \mathrm{a}$ & $22.07 \pm 2.53 \mathrm{a}$ \\
\hline
\end{tabular}

$\mathrm{CP}=$ ceruloplasmin, $\mathrm{Cu} / \mathrm{Zn}-\mathrm{SOD}=$ copper/zinc-Superoxide dismutase

$\mathrm{Mn}-\mathrm{SOD}=$ manganese-superoxide dismutase, $\mathrm{CAT}=$ catalase, $\mathrm{GSH}-\mathrm{Px}=$ glutathione peroxidase $\mathrm{MDA}=$ malondialdehyde

Note: different little letters show significant difference $(P<0.05)$. 
level. It showed that the antioxidant function of this group was the best. The antioxidant capacity of group I was lower than that of group II and group III, while the antioxidant capacity of group IV was lower than that of group III showed that the function of the antioxidant system is closely related to the content of $\mathrm{Cu}$ in the diet, but the antioxidant capacity of the body was not linear with the level of $\mathrm{Cu}$, only by increasing the content of $\mathrm{Cu}$ in the diet within a certain range can effectively improve the antioxidant capacity of the body [29, 30].

SOD is an essential component of the antioxidant system, it can antagonize and block the damage of free radicals to cells by scavenging free radicals in animals, and repair the damage in time [31, 32]. SOD can be classified into 4 groups based on the metal residue that binds to the active site: $\mathrm{Mn}-\mathrm{SOD}, \mathrm{Cu} / \mathrm{Zn}-\mathrm{SOD}$, ironsuperoxide dismutase (Fe-SOD) and nickel-superoxide dismutase (Ni-SOD) $[33,34]$. Mn-SOD helps to protect the cells from the adverse effects of excess ROS in aerobic organisms. It has the capacity to convert the superoxide anion into $\mathrm{H}_{2} \mathrm{O}_{2}$ and $\mathrm{O}_{2}[35,36] . \mathrm{Cu} / \mathrm{Zn}$ SOD is the most common of the four kinds of SOD, so increasing the level of $\mathrm{Cu}$ in vivo is helpful to synthesis and improve $\mathrm{Cu} / \mathrm{Zn}-\mathrm{SOD}$ [37]. When $\mathrm{Cu}$ nutrient is deficient or excessive, lipid peroxidation produces a lot of MDA, consumes a large amount of SOD and GSHPx, and finally cause a significant decrease of SOD and GSH-Px content, and free radical scavenging capacity decreased $[38,39]$. CP is the main carrier protein of $\mathrm{Cu}$ in blood, synthesized by $\mathrm{Cu}$ and protein in liver. It has the similar effect as superoxide dismutase in scavenging superoxide anion free radicals and inhibiting lipid peroxidation [40]. The results showed that $\mathrm{CP}$ activity increased with the increase of $\mathrm{Cu}$ content in diet. However, when $60 \mathrm{mg} / \mathrm{kg}$ was added to the diet, the activity of CP decreased significantly. The mechanism may be that the high $\mathrm{Cu}$ diet increased the deposition of $\mathrm{Cu}$ in the liver of native sheep, reduced the ability of liver to convert $\mathrm{Cu}$ to $\mathrm{CP}$, resulting the activity of $\mathrm{CP}$ decreased [41]. The results showed that the dosage of $60 \mathrm{mg} / \mathrm{kg} \mathrm{CuSO}$ had exceeded the optimum range for native sheep to copper.

\section{Conclusion}

The function of antioxidant system in $\mathrm{Cu}$ deficiency native sheep was severely reduced. Adding appropriate amount of $\mathrm{Cu}$ can improve the function of antioxidant system. According to the experimental results, added $40 \mathrm{mg} / \mathrm{kg} \mathrm{CuSO}$ to the diet, the activity of antioxidant enzyme was the highest and concentration of MDA was the lowest in grazing the native sheep, and other blood indexes were the closest to those in healthy sheep. Therefore, the optimum dietary $\mathrm{CuSO}_{4}$ level to native sheep was $40 \mathrm{mg} / \mathrm{kg}$. It is suggested that this dosage be added.

\section{Acknowledgment}

This work was supported by the project of national Key Research and Development Program of China in $13^{\text {th }}$ five-year plan (2016Yfc0502607) and the National Natural Science Foundation of China (41671041).

\section{Conflict of Interest}

The authors declare no conflict of interest.

\section{Reference}

1. SHEN X.Y., CHI Y.K., XIONG K.N. The effect of heavy metal contamination on humans and animals in the vicinity of a zinc smelting facility. Plos One, 14 (10), e0207423, 2019.

2. LIAO J.J., SHEN X.Y., HUO B., XIONG K.N. Effect of nitrogenous fertilizer on the antioxidant systems of grassland species in the Karst mountains. Acta Prataculturae Sinica, 27 (1), 169, 2018.

3. HUO B., WU T., SONG C.J., SHEN X.Y. Studies of selenium deficiency in the Wumeng semi-fine wool sheep. Biological Trace Element Research, 194 (1), 152, 2019.

4. SHEN X.Y., SONG C.J. Responses of Chinese Merino Sheep (Junken Type) on copper-deprived natural pasture. Biological Trace Element Research, 2020. https:/doi. org/10.1007/s 12011-020-02214-8.

5. SHEN X.Y., SONG C.J., WU T. Effects of Nano-copper on antioxidant function in copper-deprived Guizhou black goats. Biological Trace Element Research, 2020. https:/ doi.org/10.1007/s12011-020-02342-1.

6. SOUSA IK1, HAMAD MINERVINO A.H., SOUSA RDOS S., CHAVES D.F., SOARES H.S., BARROS IDE O., DE ARAÚJO C.A., JÚNIOR R.A., ORTOLANI E.L. Copper Deficiency in Sheep with High Liver Iron Accumulation. Veterinary Medicine International, 2012, 1, 2012.

7. H. W. BENNETTSD.V.SC, A.A.C.I. F. E. CHAPMAN A.P.T.C. Copper Deficiency in Sheep in Western Australia: A Preliminary Account of the Ætiology of Enzootic Ataxia of Lambs and an Anæmia of Ewes. Australian Veterinary Journal, 13 (4), 138, 2010.

8. WILKINSON J.M., HILL J., LIVESEY C.T. Accumulation of potentially toxic elements in the body tissues of sheep grazed on grassland given repeated applications of sewage sludge. Animal Science, 72 (1), 179, 2016.

9. KOVACIK A., ARVAY J., TUSIMOVA E. Seasonal variations in the blood concentration of selected heavy metals in sheep and their effects on the biochemical and hematological parameters. Chemosphere, 168, 365, 2017.

10. SHEN X.Y., MIN X.Y., ZHANG S.H., SONG C.J., XIONG K.N. Effect of heavy metal contamination in environment on antioxidant function in Wumeng semifine wool sheep in the Southwest China. Biological Trace Element Research, 2020. https://doi.org/10.1007/s12011020-02081-3

11. CHI Y.K., XIONG K.N., CHEN H., MIN X.Y., XIAO H., LIAO J.J., SHEN X.Y. Effect of grazing to copper pollution meadow on copper metabolism in Wumeng semi-fine wool sheep. Polish Journal of Environmental Studies, 28 (3), 1083, 2019. 
12. HUO B., WU T., CHI Y.K., MING X.Y., SHEN X.Y. Effects of Molybdenum fertilizer application on copper metabolism of Wumeng semi-fine wool sheep in copper polluted grassland. Journal of Dom Animal Ecology, 40 (7), 44, 2019.

13. SHEN X.Y. Effect of nitrogenous fertilizer treatment on mineral metabolism in grazing yaks. Agricultural Sciences in China, 8 (3), 361, 2009.

14. SONG C.J., GAN S.Q., SHEN X.Y. Effects of nanocopper poisoning on immune and antioxidant function in the Wumeng semi-fine wool sheep. Biological Trace Element Research, 2020. https://doi.org/10.1007/s12011020-02085-Z

15. SHEN X.Y., HUO B., WU T., SONG C.J., CHI Y.K. iTRAQ-based proteomic analysis to identify molecular mechanisms of the selenium deficiency response in the Przewalski's gazelle. Journal of Proteomics, 203:103389, 2019.

16. HUO B., WU T., SONG C.J., SHEN X.Y. Effects of selenium deficiency in the environment on antioxidant systems of Wumeng semi-fine wool sheep. Polish Journal of Environmental Studies, 29 (2), 1649, 2020.

17. SHEN X.Y., HUO B., GAN S.Q. Effects of Nano-Selenium on antioxidant capacity in Se-Deprived Tibetan Gazelle (Procapra picticaudata) in the Qinghai-Tibet Plateau. Biological Trace Element Research, 2020. https://doi. org/10.1007/s12011-020-02206-8.

18. SONG C.J., GAN S.Q., HE J., SHEN X.Y. Effects of nanozinc on immune function in Qianbei-Pockmarked goats. Biological Trace Element Research, 2020. https://doi. org/10.1007/s 12011-020-02182-Z

19. LI S.Q., CAO D.G., YANG Z.B. Effects of different dietary levels of copper and molybdenum on the blood biochemical index in beef cattle. Chinese Journal of Animal Nutrition, 19 (4), 17, 2007.

20. ZHANG C.Y., HU G.L., CAO H.B., GUO X.Q. Effects of dietary copper levels on immunity and activity of antioxidation enzyme of growing-laying hens. Chinese Journal of Animal Nutrition, 23 (1), 154, 2011.

21. ZHANG W. Study on dietary copper proper level of inner Mongolian white cashmere goats during the cashmere growing period. Journal of China Agricultural University, 9 (3), 36, 2004

22. WU T., SONG M.L., SHEN X.Y. Seasonal Dynamics of Copper Deficiency in Wumeng Semi-Fine Wool Sheep. Biological Trace Element Research, 197 (2), 487, 2020.

23. LIAN B., GONG X.H., MA J., YU C.S., CHEN S.J. The diagnosis and treatment of copper deficiency disease in sheep. Grass-feeding livestock, 4, 76, 2009.

24. PARCHMENT R.E. The implications of a unified theory of programmed cell death, polyamines, oxyradicals and histogenesis in the embryo. International Journal of Developmental Biology, 37 (1), 75, 1993.

25. KAUR H., WHITEMAN M., HALLIWELL B. Peroxynitrite-Dependent Aromatic Hydroxylation and Nitration of Salicylate and Phenylalanine. Is Hydroxyl Radical Involved? Free Radical Research, 26 (1), 71, 1997.

26. HANDELMAN G.J. High-performance liquid chromatography analysis of cholesterol linoleate hydroperoxide in oxidized lowdensity lipoproteins: Calibration by conjugated diene internal standard. Methods in Enzymology, 300 (1), 43, 1999.

27. SAKR H.F., ABBAS A.M., SAMANOUDY A.Z.E. Effect of vitamin $\mathrm{E}$ on cerebral cortical oxidative stress and brain-derived neurotrophic factor gene expression induced by hypoxia and exercise in rats. Journal of physiology and pharmacology: an official journal of the Polish Physiological Society, 66 (2), 191, 2015.

28. SAKIYAMA H., FUJIWARA N., YONEOKA Y. Cu,ZnSOD deficiency induces the accumulation of hepatic collagen. Free radical research, 1, 30, 2016.

29. LIU Z., WU X., ZHANG T. Influence of dietary copper concentrations on growth performance, serum lipid profiles, antioxidant defenses, and fur quality in growingfurring male blue foxes (Vulpes lagopus). Journal of Animal Science, 94 (3), 1095, 2016.

30. WANG L., HAN Y L., JIN S., ZHAO Q.S., CHEN Y.E., WANG C.L. Effects of Aqueous Copper on Reactive Oxygen Species Content and Anti-oxidation Capacity of Major Tissues in. Journal of Agro-Environment Science, 7, 1261, 2015

31. GOMEZ-ANDURO G.A., BARILLAS-MURY C.V., PEREGRINO-URIARTE A.B. The cyt- osolic manganese superoxide dismutase from the shrimp Litopenaeusvannamei: molecular cloning and exression. Developmental and Comparative Imm- unology, 30 (10), 893, 2006.

32. PERERA N.C.N., GODAHEWA G.I., LEE S., KIM M.J., HWANG J.Y., KWON M.G., HWANG S.D., LEE J. Manganese-superoxide dismutase (MnSOD), a role player in seahorse (Hippocampusabdominalis) antioxidant defense system and adaptive immune system. Fish \& Shellfish Immunology, 68, 435, 2017.

33. HUANG J.K., WEN L., MA H., HUANG Z.X., LIN C.T. Biochemical characterization of a cambialistic superoxide dismutase isozyme from diatom thallassiosiraweissflogii: cloning, expression, and enzyme stability. Journal of Agricultural and Food Chemistry, 53 (16), 6319, 2005.

34. SONG C.J., SHEN X.Y. Effects of environmental zinc deficiency on antioxidant system function in Wumeng semi-fine wool sheep. Biological Trace Element Research, 195 (1), 110, 2019.

35. WOLFE-SIMON F., GRZEBYK D., SCHOFIELD O., FALKOWSKI P. The role and evolution of superoxide dismutase in Algae. Journal of Phycology, 41 (3), 453, 2005.

36. SIRISENA D.M.K.P., PERERA N.C.N., GODAHEWA G.I., KWON H., YANG H., NAM B., LEE J. A manganese superoxide dismutase (MnSOD) from red lip mullet, Liza haematocheila: Evaluation of molecular structure, immune response, and antioxidant function. Fish \& Shellfish Immunology, 84, 73, 2019.

37. GRACE S.C. Phylogenetic distribution of superoxide dismutase supports an endo- symbiotic origin for chloroplasts and mitochondria. Life Sciences, 47 (21), 1875, 1990.

38. GUO J.Y., YU W.L., CAO H.B., HU L.M., LI Y., CHEN J.Q., YAN H., TANG Z.X. The effects of copper on rat hepatocytes proliferation activity and its free radical metabolism and the membrane potential. Chinese Journal of Veterinary Science, 36 (11), 1939, 2016.

39. LI Y.F., HE J., SHEN X.Y. Effects of Nano-Selenium poisoning on immune function in the Wumeng Semi-fine wool sheep. Biological Trace Element Research, 2020. https://doi.org/10.1007/s12011-020-02408-0.

40. RAMOS D., MAR D., ISHIDA M. Mechanism of Copper Uptake from Blood Plasma Ceruloplasmin by Mammalian Cells. PloS One, 11, 149, 2016.

41. HAMDI M., SOLÀ D., FRANCO R., DUROSOY C., ROMÉO A., PÉREZ J.F. Including copper sulphate or dicopper oxide in the diet of broiler chickens affects performance and copper content in the liver. Animal Feed Science \& Technology, 237 (237), 89, 2018. 